\title{
Does the Millennium Challenge Corporation reinforce capitalist power structures or empower citizens?
}

Article

Accepted Version

Davies, J. E. (2018) Does the Millennium Challenge Corporation reinforce capitalist power structures or empower citizens? Third World Quarterly, 39 (4). pp. 609-625. ISSN 1360-2241 doi:

https://doi.org/10.1080/01436597.2017.1401463 Available at https://centaur.reading.ac.uk/73953/

It is advisable to refer to the publisher's version if you intend to cite from the work. See Guidance on citing.

Published version at: http://dx.doi.org/10.1080/01436597.2017.1401463

To link to this article DOI: http://dx.doi.org/10.1080/01436597.2017.1401463

Publisher: Taylor and Francis

All outputs in CentAUR are protected by Intellectual Property Rights law, including copyright law. Copyright and IPR is retained by the creators or other copyright holders. Terms and conditions for use of this material are defined in the End User Agreement.

www.reading.ac.uk/centaur 
Central Archive at the University of Reading

Reading's research outputs online 


\section{Does the Millennium Challenge Corporation reinforce capitalist power structures or empower citizens?}

Joanne E. Davies ${ }^{a *}$

${ }^{a}$ School of Agriculture, Policy and Development, University of Reading, Reading, U.K.

*joanne.davies@ reading.ac.uk

Joanne Davies is Teaching Fellow in International Development at the University of Reading. Her publications and research interests focus on power analysis in development and US and Chinese engagement across sub-Saharan Africa. 


\title{
Does the Millennium Challenge Corporation reinforce capitalist power structures or empower citizens?
}

\author{
In development practice, how does 'mutual benefit' accrue, and to whom? China \\ criticises America for perpetuating capitalist power relations and claims it can \\ seek a new geo-political order based on South-South cooperation. Meanwhile, \\ there has been an extraordinary shift of emphasis toward the private sector as a \\ driver of development, but this shift is attracting increasing criticism. The \\ Millennium Challenge Corporation (MCC) - the only development agency to \\ grow in influence under the Trump administration - is evaluated in the light of \\ these two key themes. Neither China nor the private sector are successful in \\ achieving 'mutual benefit' for ordinary citizens - both replicate existing power \\ inequalities. As with the rise of both China and the private sector, the MCC also \\ enmeshes developing countries further into the existing neoliberal capitalist \\ structures. However, the advantages of the agency should not be dismissed \\ outright, as its Ruling Justly and Investing in People indicators can enhance the \\ capacity of citizens to challenge these power structures themselves.
}

Keywords: Millennium Challenge Corporation (MCC); deep marketisation; aid and conditionality; private sector-led growth; South-South Development Cooperation (SSC); China.

\section{Introduction}

The Millennium Challenge Corporation (MCC) is the only US development agency with the potential to grow in influence under the Trump administration. Republican senators and agencies argue that the MCC could become the lead development agency of the United States. ${ }^{1}$ This growing influence of the MCC is taking place during a 'paradigm shift' in foreign aid and development cooperation. ${ }^{2}$ Mawdsley et al identify two key themes in this move away from an 'aid effectiveness paradigm' to the emergence of a new 'development effectiveness' paradigm, both of which impact on the future of the MCC. ${ }^{3}$ The first of these themes is the focus on the private sector as a key development actor. The second theme is the increased incorporation of the (re)emerging powers in the shifting aid architecture. This paper evaluates the role of the 
Millennium Challenge Corporation (MCC) in the light of these two trends in development assistance: one a theoretical challenge, the other empirical.

The Organisation for Economic Co-operation and Development's Development Assistance Committee (OECD-DAC), representing the 'western' or 'traditional' group of donors, clearly reflects this first paradigm shift in development practice towards state support of the private sector. There is an increased focus on how the state can create optimal conditions for the private sector to achieve the neoliberal end goal of a global market. ${ }^{4}$ The MCC also supports the private sector to achieve economic growth. As the influence of the private sector has grown, there has been a renewed emphasis on challenging it, and on exploring the power relations which underpin the 'western' or 'traditional' donors as authors of the development agenda.

This paper explores this theoretical challenge by evaluating the role of the MCC in the light of two contrasting approaches to development finance. The mainstream 'Financing for Development' (FfD) perspective views underdevelopment as a lack of resources. In FfD, addressing this 'financing gap' is key to addressing poverty. The contrasting paradigm is what Hudson terms a 'Political Economy of Finance' (PEF) framework. ${ }^{5}$ This approach sees the financial system as a mechanism of social control, which preserves and reproduces underlying power structures. PEF views aid as an attempt to embed the capitalist system across the developing world. The development agenda's shift in emphasis towards the primacy of the private sector has led to an extraordinary privileging of private interests, a process labelled the 'deep marketisation of development. 6

The second theme examines the reimagining of the role of the (re)emerging powers as development actors - this paper focuses specifically on China. The rise of China is viewed as an empirical challenge to the influence of the MCC due to the way it characterizes itself as offering an alternative to underlying and embedded power structures. China frames its increasingly influential role as a development actor in terms of 'South-South Cooperation' (SSC), based on principles of mutual respect and mutual benefit.' Beijing accuses the traditional 'western' donors of perpetuating colonial power relationships, and asserts that it will seek a new geo-political order, challenging the power structures that subjugate poorer countries. ${ }^{8}$ Indeed, development partners in Africa have welcomed China as representing an alternative to the traditional approach to development aid. At the opening of the Chinese-funded and Chinese-built \$200 million African Union headquarters in Addis Ababa, former Ethiopian prime 
minister Meles Zenawi commented that, '[China's] commitment for a win-win partnership with Africa is one of the reasons for the beginning of the African renaissance.' ${ }^{9}$ The PEF approach accuses the West of using development finance as a tool of control. In Beijing's narrative China can wrest that control back, and return it to its SSC partners in the 'developing' world. This study explores the extent to which China does indeed pose an alternative to both the widely held neoliberal agenda and the specific influence of the MCC.

\section{Theoretical Framework: Finance for Development (FfD) vs Political Economy of Finance (PEF)}

This study evaluates the MCC in light of two competing paradigms concerning the relationship between finance and development. ${ }^{10}$ The Finance for Development (FfD) approach is the mainstream perspective in the current development narrative. ${ }^{11}$ This perspective presents underdevelopment largely as a lack of capital and resources, and these resources are seen as politically neutral - money is seen simply as a unit of account. The key question from an FfD perspective is how to fill this 'financing gap'. This approach can trace its roots back to the early days of the 'financing gap' model which argues that Official Development Assistance (ODA) should be used to plug the gap between a country's investment requirements and the finance it has at its disposal. ${ }^{12}$ Jeffery Sachs has long argued that to escape the 'poverty trap' an external injection of capital is necessary. He argues that development programmes can only succeed if sufficient ODA finance is provided. To this end, rich countries should honour their commitments to ringfence 0.7 per cent of Gross National Income (GNI) for ODA. ${ }^{13}$ On the global stage, this perspective became manifest in March 2002 in Monterrey, Mexico at the first United Nations International Conference on Financing for Development: 'For many countries in Africa... ODA is still the largest source of external financing and is critical to the achievement of the development goals.' ${ }^{14}$ This theoretical approach poses questions such as whether aid or private capital flows are preferable, and whether liberalization or strong institutions will be the most effective way of utilizing the additional resources. But whichever way it is approached, what is needed is a 'big push' of resources to kick-start development, in order that countries can be incorporated into the international financial system. ${ }^{15}$

The philosophy of the MCC falls squarely into the FfD theoretical framework. The MCC describes its role in terms of a 'mutually accountable partnership' in which 
partner country governments take the lead in setting priorities for MCC investments, but it rejects the notion of challenging existing power relationships. On the contrary, the Threshold and Compact programmes ${ }^{16}$ are designed to achieve development by economic growth, achieved through ever deeper integration into the global financial and economic systems.

The competing paradigm is termed the Political Economy of Finance (PEF). ${ }^{17}$ In this view, the financial system is seen, not as facilitating a productive allocation of resources, but rather as a mechanism of 'social control' and exploitation, vital for the 'reproduction of capitalist inequalities' ${ }^{18}$ Money is far from politically neutral. It is a social construct - created through moral, social and political relations. This perspective sees development finance in terms of a source of coercive power, functioning in much the same way as economic sanctions. The goal of integrating developing countries deeper into the international financial markets is not beneficial or benign. Through the PEF lens, development is not about simply addressing the 'financing gap'. Indeed, the way in which this finance is provided can serve to embed recipients further into a system which is predicated on their political and economic disempowerment. Critics of the FfD approach view the engagement of the International Financial Institutions (IFIs) as contributing to a neoliberal agenda in which greater liberalization of capital flows is a key aim. ${ }^{19}$

The PEF perspective of development finance draws on the arguments as proposed in Hayter's classic Aid as Imperialism ${ }^{20}$ in which aid is provided to extend and preserve the capitalist system in the developing world. ${ }^{21}$ Today, a combination of factors has seen a resurgence in the influence of this radical critique. Growing levels of inequality, particularly within countries, have led to questions about the efficacy of the neoliberal project and its ability to distribute the gains of growth fairly. The financial crisis brought into question the ability of the western financial system to sustain growth and development. A growing awareness of the 'financialisation' of the global economy, in which productive forms of capital accumulation have been replaced with ever greater levels of financial capital accumulation, is causing increasing concern. ${ }^{22}$ This is exacerbated by the way in which this drive towards financialisation is attempting to incorporate previously disengaged territories into a global system of financial capital accumulation. ${ }^{23}$ Hayter's assertion that aid is an attempt to institutionalise and embed market-based forms of social organisation is reflected in what Carroll has identified as the 'deep marketisation' of development. ${ }^{24}$ 


\section{The 'deep marketisation of development'}

Carroll argues that the development project has not stalled at the state-oriented neoliberal reform programme of the Post Washington Consensus (PWC). On the contrary, he identifies an evolution, spurred by the shifting poles of global growth, that has 'changed the landscape upon which development operates'. ${ }^{25}$ Carroll situates his argument as the latest phase of the neoliberal development programme, which he characterises as an attempt by established interests to expand patterns of accumulation. The first stage of this project was, of course, the 'roll back neoliberalism' phase, as evidenced through the structural adjustment programmes of the 1980s and 1990s. ${ }^{26}$ This was followed by the second phase in which the focus was on good governance and institutions which would deliver and assist the functioning of the markets - the 'post Washington Consensus' phase. 'Deep marketisation', as asserted by Carroll, represents the third phase of the neoliberal development policy of instilling 'competitive capitalist social relations on a truly global scale'. ${ }^{27}$ Carroll argues that this new marketisation of development both builds on the PWC, but also narrows its focus. The indicators and benchmarks which drive this new development agenda are 'oriented specifically towards the state and its progress towards establishing conditions thought to be most conducive to the private sector'. ${ }^{28}$ This critique is highly relevant for the role of the MCC, and its Economic Freedom conditionalities in particular.

\section{The MCC gains influence}

The inauguration of President Donald Trump in January 2017 raised questions regarding the direction the new administration would take on overseas aid. ${ }^{29}$ Trump's budget for Fiscal Year 2018 proposed an overall reduction of $32 \%$ to the US aid budget, a cut described as 'breathtakingly cruel' by USAID's former director of foreign disaster response. ${ }^{30}$ The MCC is the one institution with the potential to gain influence in this new development landscape. The $\$ 800$ million budget request from Trump is a cut from the previous year of $\$ 905$ million, but in the present climate it is viewed as a victory for the MCC. Republicans pay significant attention to this institution, and applaud its focus on good governance, economic growth and recipient responsibility. As Chair of the House Budget Committee in 2012, Paul Ryan proposed the shifting of all development assistance from USAID to the MCC. ${ }^{31}$ During Rex Tillerson's confirmation hearings as Trump's new Secretary of State, Tillerson mentioned the MCC 
specifically, highlighting the way in which it offered a 'different model' for development practice. He praised its focus on economic freedom, and the effective way it addressed problems of corruption and good governance. ${ }^{32}$ The MCC is highly conditional in the way it delivers assistance, providing large grant finance to countries who are obliged to meet strict indicators on: Ruling Justly; Investing in People; and Economic Freedom. This conditionality has made the institution more palatable to Trump, who has vowed to 'stop sending aid to countries who hate us'. ${ }^{33}$

With an initial endowment of just under \$1 billion, the MCC occupies a 'narrow, but very important, role in the U.S. foreign assistance framework'. ${ }^{34}$ The aim of the $\mathrm{MCC}$ is to reduce poverty through economic growth, and it pursues this aim in a targeted way. The MCC will only partner with countries that meet its definition of good governance, which includes policies designed to facilitate growth and private investment. In this way, it is easy to see why the institution might fall foul of the PEF approach to development finance, perpetuating aid as a form of social and economic control. It is significant, however, that the MCC yokes assistance to an emphasis on a government's accountability to its own citizens through its Ruling Justly and Investing in People indicators. ${ }^{35}$ Evaluations of the MCC assess the institution as a whole, looking at the aggregate effect of the indicators, and the possible benefits of the 'MCC effect'. In this paper, however, the categories of indicators are disaggregated for analysis, leading to a more nuanced assessment of the agency and its impact. It is argued here that the three separate categories of MCC indicators: Economic Freedom; Ruling Justly; and Investing in People, have very different impacts on the question of challenging underlying power structures and on longer-term development outcomes.

\section{[TABLE 1]}

The MCC frames its conditions in terms of 17 independently designed indicators which range from indicators on child health, freedom of information and civil liberties, to control of corruption and trade and fiscal policies. ${ }^{36}$ If an eligible country then rolls back progress on these indicators, funding can be, and has been, stopped. The problem with conditional development finance has often been the lack of enforcement of conditionality, largely because the drivers behind such finance have included geopolitical, security or economic calculations. ${ }^{37}$ In the case of the MCC, on the other hand, compacts have been terminated for failure to adhere to conditions, in Madagascar and Mali following coups for example, and more recently in Tanzania. ${ }^{38}$ This can prevent the possible misappropriation of development assistance that often occurs in 
settings where aid is provided in conditions of poor governance - a criticism that has been levelled at China in the past regarding assistance to Sudan and Zimbabwe.

The initial request for MCC funding is initiated by the recipient government. Because a country must meet conditions before the MCC will enter into a compact (i.e. provide funding), recipients are therefore encouraged to engage in self-initiated reforms, which have the potential of being more sustainable. ${ }^{39}$ The money is managed by a locally established Millennium Challenge Account team, with the aim of improving local capacity and ownership of the projects. The MCC describes itself as 'changing the conversation' 40 about how the US delivers foreign assistance, and is explicit about the way in which its work supports 'American values'. The competitive nature of selection, and the fact that there are genuine consequences for a failure of compliance, are crucial.

MCC investments 'align far better than those of other US government agencies with what ordinary citizens in partner countries identify as their top priorities. ${ }^{, 41} \mathrm{~A}$ working paper from the Center for Global Development uses public attitude surveys and Afrobarometer data to examine how successful the United States government has been in aligning its development assistance with the priorities of African citizens. ${ }^{42}$ Although it concludes that the US government is not particularly effective overall in this respect, the report calculates that alignment has been 'dramatically higher' in MCC compact commitment years in eligible countries compared with non-compact years in these same countries. Alignment is also higher in MCC-eligible than MCC-ineligible countries. ${ }^{43}$ It is significant that this alignment is at citizen-level, in line with the findings of public attitude surveys, rather than necessarily at the level of government-to-government relations.

The MCC is proud of the 'MCC Effect' which describes 'all the favorable implications of MCC's focus on policy performance - including country-led development and policy reform', ${ }^{44}$ and more specifically, the way in which the MCC selection criteria creates specific incentives for improved performance (as defined by the MCC). Liberia's improved record keeping on educational data and tariffs, and Sierra Leone's anti-corruption efforts, increased public health spending, reduced tariffs and increased access to credit have all been cited by the MCC as examples of this 'MCC Effect' in action. There is evidence, albeit limited, in the literature which substantiates these claims. Ohler et al found that the prospect of an initial compact provided a necessary incentive for policy reform. ${ }^{45}$ Johnson and Zajonc's study determined that countries who were candidates for Threshold or Compact agreements 
improved performance against the MCC's indicators by $25 \%$ more than non-candidate countries. ${ }^{46}$ The MCC shares success stories on its website, demonstrating the agency's impact. The Armenian foreign minister, Vartan Okasanian, asked for openness in election due to MCC funding, and Bangladesh's minister of finance stated that the country's exclusion from the MCC eligibility was due to its corruption. ${ }^{47}$ Improved irrigation in Senegal was a success, with improved livelihoods throughout the community. Additionally, Binetou Diom Ba, the president of a women's farmers association of 173 members, Senegal River Valley, 'credits MCA-Senegal for its work in convincing residents in the area to sell the land to the women. "That's the first time anyone around here can remember something like that happening.", 48

\section{MCC - changing the conversation on development?}

'MCC partner countries exercise ownership within the framework of MCC's mandate of economic growth and poverty reduction.'[author emphasis] ${ }^{49}$ The problem is that those principles themselves, and the related conditionality, are presented as axiomatic. John Hewko, former vice president of operations and compact development at the MCC, explains how the use of indicators on good governance and policy choices 'depoliticises' the eligibility process. But presenting something as a 'truth', and providing a technical definition for it, 'is a very elegant form of power' in that it 'appears to depoliticise it'. ${ }^{50}$ Even if the indicators are drawn up by a third party, the lack of acknowledgement that they are ideologically rooted and the description of this as depoliticising the process is either disingenuous or somewhat myopic. The MCC focuses almost exclusively on poverty reduction through economic growth as the criteria for evaluating funding decisions. For this to be presented as in some way apolitical appears to show a disregard for the debate on growing inequality within nations, and the way in which an exclusive focus on growth does or does not address the concerns about the way in which the fruits of this growth are distributed across society. Underlying power structures, as seen through the lens of PEF and the 'deep marketisation' critique, remain unchallenged.

A Millennium Challenge Account (MCA) Stakeholder Survey, conducted by the College of William and Mary's Institute for the Theory and Practice of International Relations in 2012, concluded that the top two leading MCA indicators of influence were Business Startup and Fiscal policy, both in the Economic Freedom category, and both vital in supporting and protecting vested interests and current power relations, and the 
private sector in particular. In contrast, of the bottom three indicators of influence, two were part of the 'Ruling Justly' category: Civil Liberties and Political Rights, both necessary to challenge power relations and empower a country's citizens.

In the case study of the Ghana Power Compact, signed by the MCC and the government of Ghana in August 2014, there were indications that the Ghanaian government had reservations about the allocation of political power. The Compact is designed to open Ghana's energy market to the private sector. A Ghanaian policy think tank, IMANI Ghana, argued that, although the coalition of stakeholders behind the Compact supported it in general, they objected to Article 7.1, which states that the implementation process 'shall not be subject to the laws of Ghana'. ${ }^{1}$ This clause shifts power from the democratically elected Ghanaian government to the US government under the auspices of the MCC. The extent to which the government of Ghana could be subject to external powers in order to benefit the private sector is a clear example of the shifting priorities of Western development actors, as argued by the 'deep marketisation' perspective.

The Economic Freedom indicators are an example of the 'deep marketization of development' in action, and the MCC is a useful tool in incorporating the developing world into the unequal power structures of a global capitalist system. This analysis also acknowledges, however, that the additional aspects of MCC conditionality - namely, the Investing in People and Ruling Justly categories, should not be dismissed. In particular, the new 'hard hurdles' of control of corruption and democratic rights mean that candidate countries cannot hope to qualify for funding if these important aspects are not addressed. The MCC would be criticized in terms of a PEF theoretical framework for the way in which it embeds actors into a system which is built on their own disempowerment.

What this paper argues, however, is that a wholesale rejection of the MCC in its current form risks 'throwing the baby out with the bathwater'. Existing power structures are, by their very nature, closely protected by those with the ability to alter them. Status quo powers will not rush to adopt new forms of development assistance that would necessarily risk their own position. We need, somehow, to get from 'here' to 'there'. By rejecting the MCC outright, valuable benefits are lost in terms of strengthening citizen voice (through a focus on 'Ruling Justly') and/or on citizen capacity (through a focus on 'Investing in People'). Power structures will not be 
dismantled before the capacity of private citizens is enhanced, and their political voice strengthened.

The MCC indicators in the Ruling Justly and Investing in People categories work to enhance both the capacity and voice of the citizens in these recipient countries. The examples given above demonstrate that, although limited, there is an 'MCC effect' which influences the behaviour of candidate countries in a way that shifts attention to the rights and opportunities of the people. The MCC does not address underlying power structures at the global level - quite the opposite. It does, however, begin to provide a voice and an avenue of change for citizens within countries, with its focus on civil rights, democracy and education. It is only by enabling citizens in this way that power structures will potentially be challenged by the very people that are currently disempowered - in this way the challenge will come from the bottom up, as it should. The disaggregated analysis of the MCC indicators offered in this paper stands in contrast to the narrative of the MCC as wholly a tool of deep marketisation, or even as a tool of American imperialism.

Soederberg provides a robust critique of the MCC - describing the underlying logic of the MCC as safeguarding: 'neoliberal globalization and American imperial dominance...[forcing states to] wholeheartedly embrace the same neoliberal discipline that has led to high levels of insecurity in the first place. ${ }^{52}$ She characterizes the Millennium Challenge Accounts (MCAs - the compacts held between the MCC and the individual countries) as appropriating the 'altruistic goals' of the Millennium Development Goals (MDGs) and 'twist[ing] the means to serve the ends of the American empire. ${ }^{53}$ For those who continue to reject the MCC wholesale as a tool of American imperialism, set on preserving the power structures of the neoliberal globalization project, there is a possible alternative: the new cooperative and 'mutually beneficial' path offered by the newly reestablished development actor, China.

\section{China and South-South cooperation: challenging the existing power structures?}

The rise of China as a development actor has led to a resurgence of hope in the power of South-South cooperation (SSC) to transform the world order. ${ }^{54}$ Will China reject the current norms that have underpinned the development narrative from its inception? Advocates of SSC point to the way in which the OECD-DAC has ensured the preservation of unequal power relationships by incorporating developing countries into the status quo via a development agenda underpinned by neoliberalism. ${ }^{55}$ Beijing is a 
willing accomplice in this narrative, with the Ministry of Commerce highlighting the western countries' 'exploitation of African resources, trade of African people, occupation of African land and destruction of African culture' as the 'essence of colonialism' and arguing that it is China, not the West, that has provided support for Africa's economic and social development. ${ }^{56}$ Beijing's most recent White Paper on Foreign Aid reiterated the basic principles of China's foreign assistance: 'mutual respect, equality, keeping promise, mutual benefits and win-win.'57 'Keeping promise' is a more recent addition, but 'mutual respect' and 'mutual benefit' are a constant theme in China's narrative of its foreign assistance provision, often presented in pointed contrast to the colonial history of the West.

Beijing accuses Western donors of perpetuating colonial power relationships and argues that it is now in a position of power from which it can address these structural inequalities by treating African interlocutors as equals, privileging their priorities in a way the West never attempted. The State-run China Daily highlights the success of the Africa-China relationship, pointing out that developing countries seek a new geopolitical and economic order. ${ }^{58}$ Statements such as these align China's rhetoric on its cooperation with Africa with the radical PEF paradigm, in a way that makes it an extremely attractive development partner to African politicians, many of whom have had their fill of western pedagogy and lecturing. ${ }^{59}$

\section{China and Africa: cooperation and mutual benefit}

China situates its engagement on the African continent in line with the South-South cooperation model, highlighting government-to-government engagement as equals. ${ }^{60}$ Beijing has cemented this approach with concrete initiatives such as the Forum on Chinese African Cooperation (FOCAC), and with a broad programme of high profile, high-level visits, coordinated around Beijing's '461' approach. ${ }^{61}$

The close ties on a more personal level between high-level governmental personnel from both China and Africa, as facilitated by regular communication and face-to-face meetings, have provided the opportunity for the African voice to be heard more clearly. The most recent Forum on China-Africa Cooperation Johannesburg Action Plan (2016-2018), resulting from the FOCAC held in South Africa in December 2015, illustrates this increased responsiveness to African priorities. Although infrastructure remains a top priority, African governments have been keen to move away from this exclusive focus, highlighting, in particular, their need for agricultural 
development and wider structural reform in order to support job creation and manufacturing. Under the section of the Plan entitled 'Economic Cooperation', the first sub-section is concerned with Agriculture and Food Security, detailing a range of initiatives designed to address agricultural modernization and sharing of agricultural research and technology. This is followed by a focus on Industrial Capacity Cooperation, including a US\$10 billion China-Africa Production Capacity Fund. Infrastructure Development is dealt with in the third sub-section, after Agriculture and Industrial cooperation, which reflects the influence of African priorities in shifting the primary focus away from a narrow spotlight on tied aid infrastructure development to include agricultural and industrial reform.

China will provide assistance even in areas of its own strategic interest. The United States began formal dispute proceedings with China in the World Trade Organisation over China's domestic support measures for its agricultural sector. ${ }^{62}$ Within weeks of the dispute being filed, however, Chinese Minister of Agriculture Han Changfu announced a US\$60 million grant to support Sudanese agriculture, and reiterated that China will not charge import fees on goods that meet specified technical requirements. ${ }^{63}$ China is also rolling out its Chinese Agricultural Technology Centres currently in 23 countries and funded under the Ministry of Commerce's aid programme, which provide technology transfer and training. ${ }^{64}$ The African priority for training and technical improvement does appear to have been addressed more comprehensively by Chinese engagement than by western initiatives, with more than 10,000 African government officials being trained in China, many in agriculture. ${ }^{65}$

In the area of industrialization, too, China's initiation of the China-Africa Production Capacity Fund was realized in January 2016. There is huge scope for Africa to benefit from increased industrialization. It is currently largely excluded from global value chains, and only provides 4 per cent of the global value added in manufacturing. ${ }^{66}$ China is aiming to move to more capital-intensive processes. Although the natural shift of these jobs would be to China's less developed neighbours, even a small percentage being moved across to Africa would make a significant difference to the continent, given Africa's extremely low starting point. The possibilities of technology transfer, training and industrial cooperation could tackle structural issues of development, Beijing would argue, in a way that western development initiatives never have. A number of African government leaders have been quick to confirm that China is doing 
what the ex-colonial powers have failed to do in the past: help Africa out of poverty. As President Uhuru Kenyatta has argued:

The perception that China is the new colonizer is a complete misrepresentation of Beijing's activities here in Africa. Achievement of mutual benefits is the basis of Sino-African cooperation. ${ }^{67}$

\section{Chinese development finance: not the same as aid}

It is important to recognize Chinese activity as something other than 'aid'. An illustrative example of the way in which this process works are the loans provided to the Chinese multinational telecommunications equipment company ZTE by China's ExIm bank and the Chinese Development Bank. The three medium-term financing agreements, provided by these state lenders in 2005, 2009 and 2012, offered a $\$ 20$ billion line of credit. This then enabled ZTE to secure contracts and offer their own supplier credits, thus facilitating their access to African markets. ${ }^{68}$ This example demonstrates that aid structured in order to support the private sector is not the preserve of the traditional donors alone. Indeed, Paul Kagame, President of Rwanda, has argued that, although aid has been helpful, it does not provide sustainable development in the way that trade and investment does, and therefore Africa welcomes this investment, from wherever it is forthcoming. ${ }^{69}$

The debate about Chinese involvement in Africa fails to give full weight to the significance of Chinese companies in shaping engagement. What has complicated the discourse is that this 'new' Chinese development model of 'mutual cooperation' in fact reflects the well-established pattern of any ExIm Bank - in China, the West or elsewhere. ${ }^{70}$ The state provides loans for business, but they are tied, as they always will be in the case of ExIm credit. The export sellers' credits that are granted to Chinese companies are intended to generate business, so conflating them with the idea of a new development model is to miss the point. Chinese companies are often operating in Africa on their own terms, and the companies can often be more bullish than Beijing. Sinosure, the state-funded Export Credit Insurance Company, has already been obliged to cover the loans that the Zimbabwean government was unable to repay, and was then understandably reluctant to issue new loans to the Mugabe government. It was Chinese companies operating in Zimbabwe that continued to offer supplier credits for construction and infrastructure work when Sinosure was increasingly reluctant to cover the growing risk of default. ${ }^{71}$ 


\section{Chinese development assistance - mutual benefit?}

China criticized the West for perpetuating unequal power relationships and promised a partnership approach to development, but it has not fulfilled that promise. James Schneider, editor of Think Africa Press, concludes that the fundamental power dynamic behind the infrastructure investment remains: resources are extracted, and finished goods and machinery are imported to facilitate that extraction. ${ }^{72}$ Rather than a new cooperative approach, Chinese development assistance in some aspects is a return to old ways of aid and finance provision that have proved damaging in the past. Some African governments are building up large amounts of debt and linking their economies inextricably to the health of the Chinese economy. These leaders are ignoring the fact that debt flows are volatile, pro-cyclical and crisis prone, and that credit and debt flows are linked to the economic conditions of the lenders rather than the borrowers. ${ }^{73}$ As Chinese projects leave African countries saddled with debt, a new skepticism is creeping in to Sino-African relations. The former governor of Nigeria's Central Bank, Lamido Sanusi, characterised Chinese involvement as 'the essence of colonialism'. ${ }^{74}$

The spectre of default is beginning to emerge across some of China's infrastructure projects, and the problem of corruption that has bedeviled traditional aid projects for decades is compounding the problem. An example from Asia can illustrate the problem. 70\% of Sri Lanka's infrastructure projects from 2009 - 2015 have been funded by Chinese investment. ${ }^{75}$ When a new government was elected in 2015, allegations of graft were levelled at the previous administration. Relations with Beijing came under increasing strain as the new government in Colombo insisted that debt accrued under their predecessors ought to be renegotiated. The country is now facing a debt crisis, with the finance minister alleging, 'Chinese loans are a big part of our problem. A bulk of the government expenditure goes into servicing them. ${ }^{76}$ The new railroad being built using Chinese funds in Kenya will increase Kenya's external debt by a third. Kenyan journalist David Ndii argues that the railroad in Kenya could have been financed through the World Bank, which could potentially have cost as little as a third of the Chinese commercial loan. ${ }^{77}$ In this context, claims of 'mutual benefit' begin to look less promising.

\section{Underlying power structures remain unchanged}


China, under the auspices of SSC, champions a radical challenge to the existing order of power, acknowledging the developing countries' search for 'a new geo-political and economic order'. ${ }^{78}$ Its engagement with the continent does not demonstrate this objective in practice. It is, however, important to recognize that Beijing's talk of 'mutual respect', numerous high-level delegations and establishment of FOCAC have addressed an area that had not featured highly on the western development agenda. China has shown commitment to many of the priorities of its African interlocutors, such as the high levels of training and scholarships it provides, and the significant impacts it is making in technology transfer and investment in high priority areas of agriculture and industry. On a more local level, although many local traders decry the way in which Chinese traders are undercutting them with cheap imported goods to catastrophic effect, ${ }^{79}$ there is also the fact that some African traders have welcomed the opportunity to source goods in China themselves. China is relatively flexible in providing visas to those African citizens who would like to travel to China to source these goods. ${ }^{80}$ This contrasts with the EU or the US where travel is made far harder.

China's 'demand-led' funding is seen as a key plank of the 'mutually beneficial' nature of China's engagement, but raises the question - who benefits? China's rejection of 'political rights' conditionality means that Chinese funding 'may be particularly easy to exploit for politicians who are engaged in patronage politics. ${ }^{81}$ A survey of studies on patronage politics indicates that political leaders tend to favour their home regions. ${ }^{82}$ Judging the birthplaces of political leaders at the first subnational administrative level (e.g. states, provinces or governorates), flows of official Chinese finance including nonconcessional loans to that region nearly triple after that leader comes to power. ${ }^{83}$ Even using the OECD definition of overseas development assistance (ODA) there is an increase of just over $75 \%$ to the region of the political leader of the country. ${ }^{84}$

Chinese engagement is neither a simple continuation of the same mode of exploitation, nor a fundamental shift to a new, mutually beneficial South-South cooperation model of development practice. There have been movements towards an increased level of cooperation and mutual respect - African governments have appreciated the Chinese approach to local priorities and an emphasis on shared learning and technology transfer. What is important to note, however, is that this Chinese approach is not designed to address the idea of underlying power structures any more than the traditional approach. There is more appreciation of treating the African governments as interlocutors on the world stage, in contrast to the highly conditional 
'scorecard' analysis of the MCC approach. But the MCC approach does address the idea of power relations on a national level. The conditionalities of the MCC address both political rights, civil liberties and investment in people in a way that is absent in the Chinese approach. And a clear difference, of course, is that Beijing would reject any shift towards democracy.

The Millennium Challenge Corporation's strict conditionality is a distillation of everything a Political Economy of Finance (PEF) approach would reject, tying African governments deeper into the power relations as dictated by the West, through strict adherence to the neoliberal-informed policy prescriptions of the US. However, its insistence on fortifying the capacity of citizens and enhancing the rule of law, together with its inclusive stance towards civil society organisations, could potentially strengthen Africa at the level of its citizens, so that mutual benefit could reach across all levels of society.

\section{Conclusions}

Those who subscribe to the PEF perspective view the actions of both Beijing and Washington as little more than 'naked imperialism'. ${ }^{85}$ It is not possible to achieve justice without 'confronting power'. ${ }^{86}$ Development finance is a source of coercive power, and, to reiterate, will always be tied to the circumstances of the lenders, not the borrowers. However, there have been minor, but nonetheless significant, alterations in the development narrative. The fact that China has provided African governments with an alternative development agenda based on cooperation has changed the frame of reference. Local ownership of development programmes has become an accepted principle. China's approach is perhaps more practical, acknowledging and respecting Africa's demand for increased training programmes, the need for technology transfer and practical support in infrastructure, agriculture and manufacturing.

The conditionality of MCC Compacts addresses some of the key issues of power distribution at the level of the citizen. The MCC scorecard for the Cote d'Ivoire in 2013 showed it failing in 15 of the 20 indicators, including those on Freedom of Information, Civil Liberties, Rule of Law and Political Rights. In a concerted effort to qualify for

MCC funding, the government undertook a series of reforms. ${ }^{87}$ By 2015, 13 indicators were deemed satisfactory and the MCC entered into a compact with Cote d'Ivoire in 2015. The 2017 MCC scorecard shows all the above indicators are now being met, including all six Ruling Justly measures. 
The MCC approach begs the question of how 'mutual benefit' accrues - and to whom. China openly criticises America for perpetuating neo-colonial power relations in its engagement with Africa. The MCC Economic Freedom indicators privilege the private sector in a manner denounced by deep marketisation theorists. Western commentators decry Chinese investment as exploitation. Neither approach addresses the global power structures that underpin these relationships. From the point of view of the individual citizen, however, an emphasis on conditionality that attempts to address Ruling Justly and Investing in People indicators through engagement with national governments across the continent could provide this 'mutual benefit'. Power relationships underpin development. It is important to consider, however, that development must move forward from its current position, with these power relationships still in place. As mentioned, we need to get from 'here' to 'there'. Power structures will not be dismantled before the capacity of private citizens is enhanced, and their political voice strengthened. For this reason, it could be wise for these citizens to hope that the President of the United States continues to be persuaded of the value of the MCC.

\footnotetext{
${ }^{1}$ Runde, MCC in the Trump Era, 4

${ }^{2}$ Mawdsley et al, A 'post-aid' world?

${ }^{3}$ Ibid.,

${ }^{4}$ Carroll, Working on, through and around the state, 379.

${ }^{5}$ Hudson, Global Finance and Development

${ }^{6}$ Carroll, Working on, through and around the state.

${ }^{7}$ Information Office of the State Council, PRC China's Foreign Aid

${ }^{8}$ China Daily.com Why is China-Africa Relationship Thriving?

${ }^{9}$ Roopanarine, China: 'rogue donor'?

${ }^{10}$ These are outlined with great clarity in Hudson, Global Finance and Development.
} 
${ }^{11}$ United Nations, Third International Conference on Financing for Development

${ }^{12}$ Chenery and Strout 'Foreign assistance and economic development'.

${ }^{13}$ Sachs, The End of Poverty, 218.

${ }^{14}$ UN, Monterrey Consensus of the International Conference on Financing for Development

${ }^{15}$ Hudson, Global Finance and Development, 56.

16 The Threshold Programme is designed to assist countries that are on the 'threshold' of being eligible for an MCC compact. It is intended to support ongoing domestic reform efforts.

${ }^{17}$ As defined by Hudson, Global Finance and Development, 12-16 and 71-86.

${ }^{18}$ Hudson, Global Finance and Development, 10.

${ }^{19}$ Soederberg, 'American empire and 'excluded states' 281.

${ }^{20}$ Hayter Aid as Imperialism, 1971

${ }^{21}$ Hudson, Global Finance and Development, 157.

${ }^{22}$ Epstein, Financialization and the World Economy

${ }^{23}$ Duménil and Lévy, 99-112

${ }^{24}$ Carroll Working on, through and around the state.

${ }^{25}$ Ibid., 378.

${ }^{26}$ Brenner and Theodore, Spaces of Neoliberalism, 26

${ }^{27}$ Carroll, Working on, through and around the state, 381.

${ }^{28}$ Ibid., 384.

${ }^{29}$ Quinn, 'US foreign aid biggest casualty', 4-5.

${ }^{30}$ Konyndyk, 'Trumps's budget breathtakingly cruel'.

${ }^{31}$ Runde, MCC in the Trump Era, 10.

${ }^{32}$ Lieberman, Tillerson outlines US aid vision, 3-4. 
${ }^{33}$ Quinn, 'Will Trump honour pledge?' 2.

${ }^{34}$ Hewko, Can the Experiment Survive? 7.

${ }^{35}$ Rose and Wiebe "Overview of Millennium Challenge Corporation"

${ }^{36}$ See https://www.mcc.gov/who-we-fund/indicators

${ }^{37}$ Hudson, Global Finance and Development, 192.

${ }^{38}$ See, for example, Lei Ravelo MCC suspends \$350M compact with Malawi

${ }^{39}$ Molenaers, Dellepiane and Faust, "Political Conditionality and Foreign Aid", 2.

${ }^{40}$ https://www.mcc.gov/about

${ }^{41}$ Rose, Overview of Millennium Challenge Corporation, 8.

${ }^{42}$ Leo Is Anyone Listening?, 10.

${ }^{43}$ Leo Is Anyone Listening?, 17.

${ }^{44}$ MCC The MCC Effect

${ }^{45}$ Ohler Does Conditionality Work?

${ }^{46}$ Johnson and Zajonc, Can Foreign Aid Create an Incentive?

${ }^{47}$ MCC Success Stories

${ }^{48}$ MCC Success Stories

${ }^{49}$ Lucas, S. Principles into Practice Country Ownership.

${ }^{50}$ Hudson, Global Finance and Development, 123.

${ }^{51}$ https://www.businessghana.com/site/news/general/145000/Ghana-renegotiatespower-compact-with-MCC

${ }^{52}$ Soederberg, 'American empire and 'excluded states' 297.

${ }^{53}$ Soederberg, 'American empire and 'excluded states'” 297.

${ }^{54}$ For further discussion and definitions of the concept of SSC, see United Nations Office for South-South Cooperation http://ssc.undp.org/content/ssc/about/what_is_ssc.html

${ }^{55}$ Gray and Gills, South-South Cooperation. 
${ }^{56}$ Sun, China's increasing interest in Africa.

${ }^{57}$ See Information Office of the State Council, China's Foreign Aid for full text

${ }^{58}$ China Daily.com Why is China-Africa Relationship Thriving?

${ }^{59}$ Opiyo, 'Stop lecturing and open up trade', 2-4.

${ }^{60}$ For further discussion of the history and principles behind the model of south-south cooperation, see http://ssc.undp.org/content/ssc/about/what_is_ssc.html

61 " 461 " is a cooperation framework proposed by China that includes four principles "equality, solidarity/mutual trust, tolerance in development issues, innovative cooperation," six major projects "industrial cooperation, financial cooperation, poverty alleviation cooperation, environmental protection cooperation, civil and cultural exchanges cooperation, peace and security cooperation, and one platform 'FOCAC."' Yun, The Sixth forum on China-Africa Cooperation

${ }^{62}$ World Trade Organisation, United States Files Dispute

${ }^{63}$ African Farming and Food Processing "China grants \$US 60 million”

${ }^{64}$ Scoones, Chinese Engagement in African Agriculture

${ }^{65}$ Scoones, Chinese Engagement in African Agriculture

${ }^{66}$ Calabrese, China-Africa Cooperation

${ }^{67}$ FOCAC, China refutes "neocolonialism" rhetoric.

${ }^{68}$ Brautigam and Gallagher, "Bartering Globalisation”, 346-8.

${ }^{69}$ Kagame, "Why Africa welcomes the Chinese"

70 Brautigam and Gallagher, "Bartering Globalisation"

${ }^{71}$ Brautigam, Chinese Loans to Africa.

${ }^{72}$ Finighan, China in Africa.

${ }^{73}$ See further discussion in Hudson, Global Finance and Development, 193-4 and 201.

${ }^{74}$ French, "China’s Wild Rush" 
75 Jiang, "China's New Development Bank"

${ }^{76}$ Ibid.

${ }^{77}$ As quoted in French, "China’s Wild Rush"

${ }^{78}$ China Daily.com Why is China-Africa Relationship Thriving?

${ }^{79}$ Lee, M., Uganda and China, 34-6.

${ }^{80}$ Lee, M., Uganda and China, 35.

${ }^{81}$ Dreher, Aid on Demand, 3.

${ }^{82}$ One study found that across a range of developing countries the birth region of the current state leader had more intense night-time light than other regions. As quoted in Dreher, Aid on Demand, 3.

${ }^{84}$ Dreher, Aid on Demand, 3.

86 See Lee, "The 21 st Century Scramble for Africa".

87 Monbiot quoted in Lee, "The 21st Century Scramble for Africa", 307.

\section{Bibliography}

African Farming and Food Processing, 'China grants \$US 60 million to support Sudanese agriculture' in 26/09/16 at http://www.africanfarming.net/crops/agriculture/china-grants-us-60mn-to-support$\underline{\text { sudanese-agriculture }}$

Ahmed, K. China goes big in Davos, $17^{\text {th }}$ Jan 2017 BBC Website:

http://www.bbc.co.uk/news/business-38644971 
Biryabarema, Elias. ‘New \$350 mln China-funded road in Uganda starts July’ New Vision (2012) at http://www.reuters.com/article/uganda-roadsidAFL6E8FR67C20120427

Brant, P. Foreign Aid with Chinese Characteristics: China Releases First White Paper on Aid WhyDev 27/4/13 http://www.whydev.org/foreign-aid-with-chinesecharacteristics-chinas-first-foreign-aid-white-paper/

Brautigam, D. and K.P. Gallagher. "Bartering Globalisation: China’s commoditybacked finance in Africa and Latin America”, Global Policy, 5 (3) (Sept. 2014), 346352.

Brautigam, D. Chinese Loans to Africa: What's the Real Deal? CARI Policy Roundtable You Tube accessed 21/7/16 at https://www.youtube.com/watch?v=nc2nJAUR8jU

Brenner, Neil and Theodore, Nik. Spaces of Neoliberalism: Urban Restructuring in North America and Western Europe Oxford, U.K.: Wiley-Blackwell, 2002.

Calabrese, Linda. China-Africa Cooperation: a new dawn for African industry? London: Overseas Development Institute $8^{\text {th }}$ January 2016

Carroll, Toby. 'Working On, Through and Around the State: The Deep Marketisation of Development in the Asia-Pacific', Journal of Contemporary Asia 42 , No. 3 (2012): $378-404$ 
Center for Global Development website, accessed Aug-Nov 2016: www.cgd.org

Chang, H-J. and Grabel, I. Reclaiming Development: An alternative economic policy manual, London: Zed, 2004.

Chenery, H.B., and Strout, A.M., 'Foreign assistance and economic development.' The American Economic Review, LVI, No. 4, Part I, September 1966

ChinaDaily.com Why is China-Africa Relationship Thriving? at africa.chinadaily.com.cn/2015-12/05/content_22632869.htm_Accessed 13/9/16

Dollar, David, Wenjie Chen and Heiwai Tang Why is China investing in Africa? New York: Brookings, 12/8/15 at https://www.brookings.edu/research/

Dreher, Axel et al. Aid on Demand: African Leaders and the Geography of China's Foreign Assistance, Williamsburg, VA: AidData, Working Paper 3, November 2014

The Economist. 'How Donald Trump thinks about trade,' $9^{\text {th }}$ Nov. 2016

Epstein, G. Financialization and the World Economy Camberley, UK: Edward Elgar Publishing, 2005.

Finighan, Adrian. China in Africa: Investment or Exploitation? Al Jazeera Inside Story 4/5/14 http://video.aljazeera.com/channels/eng/videos/inside-story---china-in- 
africa\%3A-investment-or-exploitation

\%3F/3535886743001;jsessionid=1BA0FAFEF126791B30747164C00DC5B0

Forum on China-Africa Cooperation (FOCAC), Spotlight: China's pledge to Africa refutes "neocolonialism" rhetoric $8^{\text {th }}$ Dec. 2015

http://www.focac.org/eng/ltda/dwjbzjjhys_1/t1322064.htm

French, H. 'Into Africa: China's Wild Rush' The International New York Times, $17^{\text {th }}$ May 2014

Gracie, C, China's gamble for global supremacy, 27 ${ }^{\text {th }}$ Jan. 2017 BBC Website: http://www.bbc.co.uk/news/world-asia-china-38754047

Gray, Kevin and Barry K. Gills. (2016) South-South cooperation and the rise of the Global South, Third World Quarterly, 37:4, 557-574, doi: 10.1080/

01436597.2015.1128817

Guttman, J., Sy, A., Chattopadhyay, S. Financing African Infrastructure: can the world deliver? New York: Brookings (2015)

Haddadin, F. Foreign Aid under a Trump Presidency, Foreign Policy Association Blog $3^{\text {rd }}$ Dec. 2016. http://foreignpolicyblogs.com/2016/12/03/foreign-aid-trump-presidency/

Hewko, J. (2010) Millennium Challenge Corporation: can the experiment survive?

Washington D.C.: Carnegie Endowment for International Peace Democracy and Rule of Law Program No. 109 March 2010 at

http://carnegieendowment.org/files/millenium_challenge_corp.pdf 
Hudson, David. Global Finance and Development Abingdon: Routledge, 2015.

Information Office of the State Council, The People's Republic of China China's Foreign Aid July 2014.

http://ssc.undp.org/content/dam/ssc/dgspaces/China/files/China\%202nd\%20White\%20P aper\%20on\%20Foreign\%20Aid\%202014.pdf

Jiang, Yang. China's new development bank and infrastructure-led growth Oslo: NUPI Norwegian Institute of International Affairs Policy Brief, 2016.

Johnson, S. 'China by far the largest investor in African infrastructure', The Financial Times 30/11/15 at https://next.ft.com/content/716545c0-9529-11e5-ac15-0f7f7945adba

Johnson, D., Zajonc, T. Can Foreign Aid Create an Incentive for Good Governance? Evidence from the Millennium Challenge Corporation. Harvard University: Center for International Development, 2006.

Kagame, Paul. 'Why Africa welcomes the Chinese', The Guardian, 2/11/09 at https://www.theguardian.com/commentisfree/2009/nov/02/aid-trade-rwanda-china-west

Konyndyc, J. 'Trump's aid budget is breathtaking cruel - cuts like these will kill people' The Guardian 30/05/17 
Lebovic, James H. 'The Millennium Challenge Corporation: Organizational Constraints on US Foreign Aid, 2004-11' World Development 58 (June 2014) 116-129.

Lee, M. “The $21^{\text {st }}$ Century Scramble for Africa” Journal of Contemporary African Studies 24 (3), 2006, 303-330.

Lee, M. Uganda and China: Unleashing the Power of the Dragon, Uppsala: Nordic Africa Institute, 2007.

Lei Ravelo, J. MCC suspends $\$ 350$ M compact with Malawi Devex $26^{\text {th }}$ March 2012 https://www.devex.com/news/mcc-suspends-350m-compact-with-malawi-77829

Leo, Benjamin. Is Anyone Listening? Does US foreign assistance target people's top priorities? Washington D.C.: Center for Global Development Working Paper No. 348 December 2013.

http://www.cgdev.org/sites/default/files/overview-mcc-brief.pdf

Lieberman, A. Rex Tillerson outlines US aid vision, with few commitments to climate change and health, during Senate hearings, New York: Devex $11^{\text {th }}$ Jan. 2017 https://www.devex.com/news/rex-tillerson-outlines-us-aid-vision-with-fewcommitments-to-climate-change-and-health-during-senate-hearings-89436

Lucas, S. MCC Principles into Practice Country Ownership, Washington D.C.: MCC https://assets.mcc.gov/reports/paper-2011001093802-principles-countryownership.pdf 
Mawdsley, Emma 'A 'post-aid world'? Paradigm shift in foreign aid and development cooperation at the 2011 Busan High Level Forum', The Geographical Journal 180, Issue 1 March 2014: 27-38

Millennium Challenge Corporation website: www.mcc.gov Accessed Aug-Nov 2016 See in particular: https://www.mcc.gov/about https://www.mcc.gov/who-wefund/indicators https://www.mcc.gov/news-and-events/feature/mcc-effect

Molenaers, Nadia, Sebastian Dellepiane and Jorg Faust. 'Political Conditionality and Foreign Aid, World Development, 75 (2015) 2-12.

Naim, M. "Washington Consensus: A Damaged Brand" Financial Times, 28/10/2002

New Vision. 'China helping Uganda improve road network', $30^{\text {th }}$ December 2012

Öhler, H., Dreher, A., Nunnenkamp. A. Does Conditionality Work? A Test for an Innovative US Aid Scheme. European Economic Review 56 No.1 (2012): 138-153

Organisation for Economic Cooperation and Development, Rome Declaration on Harmonization 2003 www.oecd.org/development/effectiveness/31451637.pdf ISBN 9264-19982-9 
Opiyo, D. 'Stop lecturing and open up trade, Raila tells the West', Daily Nation $4^{\text {th }}$ Aug. 2009

Publish What You Fund, 2016 Aid Transparency Index Launch Publish what you fund and Center for Global Development, Washington D.C. $13^{\text {th }}$ April 2016 at http://ati.publishwhatyoufund.org/live-2016-aid-transparency-index-launch/

Quinn, B. 'US foreign aid expected to be biggest casualty of Trump's first budget' The Guardian $27^{\text {th }}$ Feb. 2017

Quinn, B. 'Will Trump honour pledge to 'stop sending aid to countries that hate us'? The Guardian $13^{\text {th }}$ Nov. 2016

Rieffel, Lex and James W. Fox. Strengthen the Millennium Challenge Corporation: Better Results are Possible, New York: Brookings Policy Brief Series (2008)

Rodrik, D. "Goodbye Washington Consensus, Hello Washington Confusion”, Journal of Economic Literature, 44 (4) 973-987.

Rodrik, D., Subramanian, A. and Trebbi, F. (2004) 'Institutions Rule: The Primacy of Institutions over Geography and Integration in Economic Development', Journal of Economic Growth, 9 (2): 131-165.

Roopanarine, L. 'China: 'rogue donor' or beacon of south-south cooperation?' The Guardian $2^{\text {nd }}$ April 2013 
Rose, S. and F. Wiebe. 'An Overview of the Millennium Challenge Corporation' January 2015, Center for Global Development

http://www.cgdev.org/sites/default/files/overview-mcc-brief.pdf

Runde, D., A. Milner and J. Santoro. The Millennium Challenge Corporation in the Trump Era Washington D.C.: Center for Strategic and International Studies 2017 Download available from: https://www.csis.org/analysis/millennium-challengecorporation-trump-era

Sachs, J. 2005. The End of Poverty New York: Penguin Press

Scoones, Ian. Chinese Engagement in African Agriculture is Not What it Seems at The Conversation http://theconversation.com/chinese-engagement-in-african-agriculture-isnot-what-it-seems-56779

Soederberg Susanne. 'American empire and 'excluded states': the millennium challenge account and the shift to pre-emptive development', Third World Quarterly 25 No. 2 (2004): 279-302.

Sun, Yun. 'China's increasing interest in Africa - benign but hardly altruistic' Washington D.C.: Brookings Institution, 2013 https://www.brookings.edu/blog/upfront/2013/04/05/chinas-increasing-interest-in-africa-benign-but-hardly-altruistic/ 
Sun, Yun. The Sixth Forum on China-Africa Cooperation: new agenda and new approach? 2015 Africa Growth Initiative New York: Brookings https://www.brookings.edu/wp-content/uploads/2016/07/china-africa-cooperation$\underline{\text { sun.pdf Accessed 12th October } 2016}$

United Nations Office for South-South Cooperation www.ssc.undp.org

United Nations Department of Economic and Social Affairs. Monterrey Consensus of the International Conference on Financing for Development Monterrey, Mexico, 18-22 March 2002 http://www.un.org/esa/ffd/monterrey/MonterreyConsensus.pdf

United Nations Third International Conference on Financing for Development Addis Ababa $13^{\text {th }}-16^{\text {th }}$ July 2015

http://www.un.org/esa/ffd/ffd3/

Waswa, Sam. 'Chinese ICT Project to Employ 10000 Ugandan Youths' Chimp Reports $5 / 2 / 15$

World Trade Organisation, United States files dispute challenging Chinese agricultural subsidies, World Trade Organisation News Items $14^{\text {th }}$ September 2016 at https://www.wto.org/english/news_e/news16_e/ds511rfc_14sep16_e.htm

Xinhua News, China-Africa industrial capacity cooperation fund starts operation, 07/01/16 at: http://news.xinhuanet.com/english/201601/07/c_134987683.htm

Word Count: 8669 including all references 
$\longrightarrow$ 